Informatika i sistemy upravleniya. - 2018. - No. 2(56). - P. 131-135.

Saakyan R.R. (rsahakyan@yahoo.com), Shpekht I.A.

Academy of Marketing and Socio-Information Technologies

\title{
FORECASTING THE BEHAVIOR OF CUSTOMERS BASED ON MACHINE LEARNING
}

The article is devoted to the problems of developing an intellectual system in the field of forecasting the behavior of customers who use the food delivery service based on the use of machine learning methods for planning the work of the delivery service.

Keywords: intelligent system, machine learning, forecasting customer behavior, delivery service.

DOI: 10.22250/isu.2018.56.131-135

For citation:

Saakyan R.R., Shpekht I.A. FORECASTING THE BEHAVIOR OF CUSTOMERS BASED ON MACHINE LEARNING // Informatika i sistemy upravleniya. - 2018. - No. 2(56). - P. 131-135. 